\title{
Two-Stage Data Envelopment Analysis of Spanish Regions: Efficiency Determinants and Stability Analysis
}

\author{
José Solana-Ibáñez ${ }^{1}$, Manuel Caravaca-Garratón², Lorena Para-González
}

\begin{abstract}
The purpose of this paper is to examine the hypothesis that the efficiency of Spanish tourism regions for the period 2005-2013 is determined by a group of contextual variables. In contrast with monitoring reports based on descriptive methods, this paper uses the Data Envelopment Analysis (DEA) bootstrap semiparametric procedure to investigate efficiency determinants. An innovative analysis addresses the problem of the stability of efficiency estimates of random changes in the isolated exogenous variables. The statistical significance of the potential attractors can offer a tool for strategic decisions, and no previous work compares the stability analysis results to the estimates derived from the two-stage algorithm. The model appropriately fits the data, with all the coefficients being of the correct sign and statistically significant. Hence, the fact that the exogenous variables influence the hypothesis is confirmed by the results, and the stability analysis helps to verify the significance of each variable. We also extend the traditional DEA analysis by exploring efficiency and productivity changes using the slacks-based measure (SBM) model and the bootstrapped Malmquist index approach to obtain total productivity growth estimates.
\end{abstract}

KEY WORDS: $\quad$ data envelopment analysis (DEA); destination performance; efficiency determinants; stability analysis; two-stage double bootstrap DEA

JEL Classification: $\quad$ M20, O18, R11

1 University Centre of Defence at the Spanish Air Force Academy, Department of Economics and Juridical Sciences;

2 University Centre of Defence at the Spanish Air Force Academy, Department of Sciences and Informatics

\section{Introduction}

The Spanish-European tourism industry has recently experienced some of the most challenging times in its history. In 2010, recovery in Spain followed the global

Correspondence concerning this article should be addressed to: José Solana-Ibáñez, University Centre of Defence at the Spanish Air Force Academy; Department of Economics and Juridical Sciences; C/Coronel López Peña s/n, 30720, Santiago de la Ribera, Murcia, Spain. T: +34968189956, F: +34968189970. E-mail: jose.solana@cud.upct.es trend; in 2012, Spanish tourism revenues generated a surplus of 31,610 million euros, which was sufficient to cover the trade balance deficit of approximately $123 \%$. Taking the information published by the Spanish Institute of Tourism Studies into consideration, it is extraordinary that at the end of 2015 (November), the cumulative number of tourists had reached 64.6 million (65 million at the end of 2014), with a $2.2 \%$ of year-to-year variation rate $(5.6 \%$ at the end of 2014$)$ and a cumulative year-to-year rate of $3.8 \%$ (7.1\% at the end of 2014). 
In the current scenario of great pressure from the competition, performance is becoming a key issue. In recent decades, the Destination Competitiveness Theory body of research has served as the basis for a number of studies, particularly in conceptual models such as Crouch and Ritchie (1999; 2005), Ritchie and Crouch (2000b; 2003), Mazanec, Wöber and Zins (2007), Crouch (2007; 2011), Benito-López, SolanaIbáñez and López-Pina (2014) and Assaf and Josiassen (2016). Emphasis has been placed on the clear need to direct research towards a better understanding of the attributes of competition. As a consequence, a growing number of initiatives has supported the need to measure and monitor tourist destinations. The 2015 Travel and Tourism (T\&T) Competitiveness Index (TTCI) from the World Economic Forum (WEF) reveals that the world's leading country is Spain. The concern has sparked similar initiatives at the national level, such as the MONITUR report on Spanish Regions (also called Autonomous Communities - ACs).

Competitiveness refers to the ability to gain an advantage from available resources. However, the present study aims to extend the literature in Tourism Destination "Performance" by determining whether Spanish regions are using their resources optimally, or to what extent a destination is maximizing its outputs from its inputs. This paper therefore focuses on efficiency and productivity, as well as on testing the significance of the determinants potentially affecting performance.

First, this paper contributes to this objective through its use of Data Envelopment Analysis (DEA), an internationally accepted mathematical technique for measuring efficiency. We exploit the advantage that resource utilization in technical efficiency is viewed as an approximation of destination performance. Using this technique, we assess the position of each of the 17 Spanish regions, or autonomous communities (AC), for the period 2005-2013, according to their levels of the chosen discretional variables (inputs and outputs) for the defined measure. We extend traditional DEA analysis by exploring the slacksbased measure (SBM) model to ascertain the best performing destinations. In addition, a bootstrapped Malmquist index approach is also presented to obtain total productivity growth estimates.

Second, this work will analyze the hypothesis that the efficiency of Spanish tourism regions is deter- mined by a group of contextual or exogenous variables that can explain the level of efficiency. This analysis is conducted by applying the Simar and Wilson $(2007 ; 2011)$ procedure to bootstrap the DEA scores with a truncated regression to estimate the effect of a selection of factors on robust DEA estimates. The identification of tourism performance determinants is not an aim of this study, however, as this has already been investigated in other works such as Assaf and Josiassen $(2012 ; 2016)$.

Third, to determine the significance of each variable, an innovative analysis is included with the goal of studying the efficiency estimates and stability given small changes in the isolated variables of the problem. For this purpose we define the Stability Coefficient, whose magnitude reveals the effect of each exogenous variable in the efficiency estimates, thus complementing the estimates derived from the Simar and Wilson (2007; 2011) algorithm.

The study is important because the significance or non-significance of a certain factor can provide tourism policymakers with accurate information for future strategic decisions. Moreover, no previous work has compared stability analysis results to the estimates derived from the two-stage double bootstrap algorithm used.

This paper is organized as follows. In the next section, the theoretical framework is presented. The third section explores the methodology. The fourth section is devoted to the sample and variables chosen for the first-stage and second-stage DEA analysis. In Section 5 , we present the results of the DEA basic radial and SBM models, as well as the productivity growth estimates and the analysis of the efficiency determinants obtained from applying the two-stage procedure to Spanish regions for the period 2005-2013. Finally, we present our conclusions.

\section{Theoretical framework}

International tourism has the potential to be a driving force in the economies of industrializing countries during the 21st century, especially in Asia. Countries like Spain must develop strategies to make use of their comparative advantages to achieve competitive advantage, since, as Gooroochurn and Sugiyarto (2005, p. 25) predict: "the issue is especially important for countries that rely heavily on tourism". Strong competi- 

overview in this regard can be found in Assaf and Agbola (2011), Fuentes (2011), Barros et al. (2011) and Ribes, Rodriguez and Jiménez (2011).

The Simar and Wilson (2007) double DEA bootstrap procedure is used to evaluate how efficiency varies with the selection of determinants of tourism destination performance. This two-stage procedure used is relatively novelty because only a few very recent studies of this type can be found: Barros and Dieke (2008b), Assaf and Cvelbar (2010), Assaf and Agbola (2011), Barros, Botti, Peypoch, and Solonandrasana (2011a), Assaf, Josiassen and Cvelbar (2012), Assaf, Barros and Josiassen (2012) or Hathroubi, Peypoch and Robinot (2014) in the hotel sector; Assaf, Barros and Machado (2011) in travel agency business; Barros et al. (2011), Assaf and Josiassen (2012) or Benito-López et al. (2014) in the destinations sector; Barros and Dieke (2008a), Barros (2008), Gitto and Mancuso (2010), Barros, Managi and Yoshida (2010), Tsekeris (2011), Perelman and Serebrisky (2012), Tsui, Gilbey and Balli (2014) or Merkert and Assaf (2015) in the airport business, or Assaf, Deery and Jago (2011) in restaurants.

Consequently, a fundamental novelty of the empirical illustration presented will be the careful attention conferred to the second-stage results derived from two-stage DEA procedures. In this area, a deeper analysis into the importance of each exogenous factor remains inconclusive. Accordingly, to determine the significance of each exogenous variable potentially affecting the efficiency of a group of DMUs, this paper proposes an innovative analysis with the goal of studying the stability of efficiency estimates with regard to small changes in the isolated variables of the problem. To provide new evidence we use data from 17 Spanish regions over the period 2005-2013. We select a group of well-known Spanish tourism attractors and apply the Simar and Wilson (2007) two-stage bootstrap algorithm and illustrate how the SCs strengthen knowledge concerning the significance of each considered factor.

\section{Methodology}

\subsection{Data Envelopment Analysis}

Farrell (1957) is the pioneering empirical work to estimate efficiency scores, which has been popular- ized by Charnes, Cooper and Rhodes (1978) and Banker, Charnes and Cooper (1984) through the use of linear programming techniques. It supposes a group of $n$ DMUs, DMU $, j=1,2, \ldots, n$, for which we consider a common set of " $m$ " inputs, $\left\{\mathrm{x}_{\mathrm{ij}}\right\}_{\mathrm{i}=1}^{\mathrm{i}=\mathrm{m}}$, and "s" outputs, $\left\{\mathrm{y}_{\mathrm{r} j}\right\}_{\mathrm{j}=1}^{\mathrm{j}=\mathrm{s}}$. The production possibility set of all feasible input and output vectors, $\Psi$, is defined as follows:

$\Psi=\left\{(x, y) \in R_{+}^{m} \cdot R_{+}^{s}: x\right.$ can produce $\left.y\right\}$

We will assume an output orientation, i.e., the Spanish tourism regions aim to maximize their activity revenue (output) given the inputs. The Farrell output-oriented technical efficiency measure for the assumption of constant returns to scale (CRS) is derived by solving the following linear programming (we label the DMU evaluated by the subscript $o$ ):

$\left[\begin{array}{c}\operatorname{Max} \delta \\ \text { s.t. } \\ x_{i o} \geq \sum_{j} \lambda_{j} x_{i j} \quad i=1,2, \ldots, m \\ \delta y_{r o} \leq \sum_{j} \lambda_{j} y_{r j} \quad r=1,2, \ldots, s \\ \lambda_{j} \geq 0 \quad j=1,2, \ldots, n\end{array}\right]$

CRS measures the overall efficiency for each unit (pure technical efficiency and scale efficiency). The variable returns to scale (VRS) efficiency model, by Banker et al. (1984), is estimated by restricting $\Sigma \lambda_{j}=1$; it provides measures of pure technical efficiency. The scale efficiency score by Färe Grosskopf and Lovell (1985) is obtained by dividing the CRS score by the VRS score. The estimates of the efficiency scores, $\hat{\delta}_{j}(\mathrm{j}=1,2, \ldots \mathrm{n})$, are bounded between unity and infinity. A unitary value implies that the observed production coincides with the potential production and that the DMU is efficient. If it exceeds the unity, the DMU is not efficient.

As an alternative to conventional radial DEA models, we also consider the Slack-Based-Measured (SBM) model by Tone (2001). Its non-radial efficiency measure draws on all inefficiency sources, offering a more exhaustive explanation regarding why a destination may become relatively efficient or inefficient over time. The non-oriented CRS SBM 
efficiency measure is derived by solving the following linear programming:

$$
\left[\begin{array}{c}
\frac{1}{m}\left(\sum_{i} \frac{s_{i}^{-}}{x_{i o}}\right) \\
\frac{1}{s}\left(\sum_{i} \frac{s_{r}^{+}}{y_{r 0}}\right) \\
\text { s.t. } \\
x_{i o}-s_{i}^{-}=\sum_{j} \lambda_{j} x_{i j} \quad i=1,2, \ldots, m \\
y_{r o}+s_{r}^{+}=\sum_{j} \lambda_{j} y_{r j} \quad r=1,2, \ldots, s \\
\lambda_{j} \geq 0 \quad j=1,2, \ldots, n ; s_{i}^{-} \geq 0 \forall i ; s_{r}^{+} \geq 0 \forall r
\end{array}\right]
$$

The SBM efficiency score, $\theta$, is between 0 and 1 , considering that if $\theta=1$, the region is efficient. When a region becomes SBM efficient, all slacks (regional input excesses and output shortfalls) are zero in any optimal condition, being the destination located on the efficiency frontier.

\subsection{Malmquist Productivity Index}

To measure whether the productivity of Spanish regions has progressed over time, we use the Malmquist productivity index, a quantity index defined using the ratio of distance functions that was originally introduced by Malmquist (1953). Following the decomposition by Färe, Grosskopf, Norris and Zhang (1994), the MI index between two periods, $t$ and $t+1$, is calculated as:

$\operatorname{MI}_{0}^{\mathrm{t}, \mathrm{t}+1}=\left[\frac{\mathrm{d}_{0}^{\mathrm{t}}\left(\mathrm{x}^{\mathrm{t}+1}, \mathrm{y}^{\mathrm{t}+1}\right) \cdot \mathrm{d}_{0}^{\mathrm{t}+1}\left(\mathrm{x}^{\mathrm{t}+1}, \mathrm{y}^{\mathrm{t}+1}\right)}{\mathrm{d}_{0}^{\mathrm{t}}\left(\mathrm{x}^{\mathrm{t}}, \mathrm{y}^{\mathrm{t}}\right) \cdot \mathrm{d}_{0}^{\mathrm{t}+1}\left(\mathrm{x}^{\mathrm{t}}, \mathrm{y}^{\mathrm{t}}\right)}\right]^{1 / 2}=$

$=\underbrace{\mathrm{TE} \Delta_{0}^{\mathrm{t}, \mathrm{t}+1} \cdot \mathrm{SE} \Delta_{0}^{\mathrm{t}, \mathrm{t}+1}}_{\text {efficiency change }} \cdot \underbrace{\mathrm{T} \Delta_{0}^{\mathrm{t}, \mathrm{t}+1}}_{\text {technical change }}$

The decomposition takes the Färe, Grosskopf, Lindgren and Roos (1994) efficiency change component (EC), calculated relative to the CRS technology, and decomposes it into a pure efficiency change component, TE $\Delta$ in (5), calculated relative to the VRS technology and a scale component, SE $\Delta$ in (5), which captures changes in the deviation between the CRS and VRS technology. The MI and its components can be greater than, equal to, or less than 1 according to productivity growth, stagnation or decline between periods $t$ and $t+1$. Simar and Wilson (1999) extended a bootstrapping procedure to determine the statistical properties of the Malmquist index.

\subsection{Efficiency Determinants and Stability Analysis}

The causes of inefficiency are analyzed by considering a group of external factors, denoted by $\mathrm{Z} \in \mathrm{Z} \subset \mathrm{R}^{\mathrm{r}}$; such variables, which are neither inputs nor outputs and are not under control of the DMU, may influence the production process.

The two-stage approach by Simar and Wilson (2007), which is complemented in Simar and Wilson (2011, 2015), has assumed the turning point in the treatment of exogenous factors. The model takes the following form:

$\delta_{\mathrm{i}}=\psi\left(\mathrm{z}_{\mathrm{i}}, \beta\right)+\xi_{\mathrm{i}}$

As true efficiency scores, $\delta_{i}$, are not observed in the first stage, technical efficiency is estimated by DEA ignoring Z. Estimates from the first stage, $\hat{\delta}_{i}$, or biascorrected estimator, $\hat{\hat{\delta}}_{\mathrm{i}}$, replace the unobserved $\delta_{\mathrm{i}}$ and, in the second stage, are regressed on environmental covariates, $z_{\mathrm{i}}$. In accordance with Simar and Wilson (2007), a truncated normal distribution is assumed.

The statistical significance of each exogenous variable under the two-stage procedure can be complemented through the Stability Analysis. Concretely, it is relevant to know how changes in the exogenous variables may affect efficiency. Suppose that $x$ is denoted as a $n$-tuple of real numbers, representing one of the exogenous variables of our problem in a particular year. If we consider that the efficiency coefficients vector is an $m$-tuple of real numbers denoted by $f$, we introduce the stability coefficient, $\Omega$, following Trefethen and Bau (1997):

$\Omega=\lim _{\in \rightarrow 0^{+}}\left\{\sup _{\|\Delta x\| \leqslant \epsilon}\left(\frac{\|\mathrm{f}(\mathrm{x}+\Delta \mathrm{x})-\mathrm{f}(\mathrm{x})\| /\|\mathrm{f}(\mathrm{x})\|}{\|\Delta \mathrm{x}\| /\|\mathrm{x}\|}\right)\right\}$

This expression represents the largest value of the fractional change ratio in the output function $f$ to a fractional change in the variable $x$, where $\Delta x$ is considered a small increment in the selected variable.

Therefore, $\Omega$ is a positive real number that represents how sensitive efficiency is to small changes in an exogenous variable. When $\Omega$ is in the order of the unity, the problem is said to be well-conditioned, which indicates a weak exogenous factor. In our study, we slightly perturb $x$ by adding different per- 
centages chosen inside a short interval of variation. We compute $\Omega$ for the 2005-2013 period when each isolated attractor is perturbed. With the objective of determining the significance of each exogenous variable, we continue making the change in $\Omega$ through the years.

\section{Sample and variables}

Our initial sample comprises data from 17 Spanish ACs between 2005 and 2013. We will consider that the regions' goal is to achieve maximum output once given inputs. In this sense, according to Botti, Peypoch and Solonandrasana (2008), Barros et al. (2011) or Benito-López et al. (2014), we use length of stay as the appropriate variable to examine performance, and as a unique output, we use the number of bed nights (BEDNIG), namely, the total number of nights a traveler stays in an establishment. Chosen inputs are the accommodation capacity (ACCOM), the total number of beds available, and the input tourist arrivals (NUMAR), which is the total number of people staying at least one night in an establishment. As a mean for the period, 5.7 million tourist arrivals assume 22.2 million bed nights. The discretionary variables used for the first stage of DEA analysis, i.e., inputs and outputs, were chosen with the aim of obtaining an efficiency score for each region.

Regarding the second stage of Simar and Wilson's (2007) procedure, we will use a group of environmental factors recognized by the Spanish MONITUR Report as having the highest impact in Spain. The environmental factors to be considered are COAST, a dummy variable with null value if the region is coastal, and 0 if not; BICUL, the number of cultural properties; and MUSEUM, which is the number of museums and collections. Moreover, MICE measures the importance of each region in Conference and Conventions Tourism on the basis of the percentage of meeting attendance; NATUR measures the importance of nature tourism; GOLF measures the number of federated clubs in a region; SKI is a dummy variable with a unitary value for regions with at least $1 \mathrm{~km}$ of skiable runs and 0 otherwise; the FOOD variable measures the number of restaurants per region; and finally, SHOP is a proxy for shopping tourism, which is based on the number of retailers per region.

\section{Results}

\subsection{Efficiency and Productivity}

The first stage in the assessment, i.e., considering only the discretional input and output variables, provides the efficiency coefficients for the DEA ratio outputoriented models. As known from Simar and Wilson (1998) or Wheelock and Wilson (2008), these DEA estimators are biased downward, and this must consequently be considered.

The Farrell type DEA score is between 0 and 1, meaning the efficiency of a DEA score equal to 1 . Table 1 shows efficiency scores for the average data of the 2005-2013 period, with $\hat{\delta}_{\mathrm{CRS}}$ for CRS assumption, $\hat{\delta}_{\mathrm{VRS}}$ for VRS, $\hat{\delta}_{\text {NIRS }}$ for non-increasing returns to scale, and $\hat{\delta}_{\mathrm{SE}}$ for scale efficiency.

The $\hat{\delta}_{\text {CRS }}$ measures the overall efficiency for each region, and reference sets may be composed of efficient DMUs of any size. Under this assumption the average efficiency score is 0.612 ( 0.550 for the average period data in Table 1). This means that on average and given the inputs, Spanish regions could improve their output by $38.8 \%$ (approximately $45 \%$, considering the average period data). It would be more functional to establish comparisons among units of similar behavior than the one evaluated, which could be accomplished by pure technical efficiency, $\hat{\delta}_{\mathrm{VRS}}$. Under the VRS assumption, the average efficiency score is higher, reaching 0.735 ( 0.715 for the average period data in Table 1$)$. The VRS score corresponds to management efficiency and can be translated as managerial skills.

Scale inefficiency is the result of the units operating on an unfavorable scale. Following Färe and Grosskopf (1985), the ratio $\hat{\delta}_{\mathrm{CRS}} / \hat{\delta}_{\mathrm{VRS}}$ runs the scale efficiency coefficients, $\hat{\delta}_{\mathrm{SE}}$, and a region is scale efficient when its size of operation is optimal. The $\hat{\delta}_{\text {NIRS }}$ scores help to measure the returns to scale, which concerns how the production process can be scaled up and down for each region. For those with DRS (eight regions), an increase in input would imply a lower than proportionate increase in output; this could be interpreted as satiation in arrivals given the characteristics of the region. The mean efficiency scale, $\hat{\delta}_{\mathrm{SE}}, 0.774$ in table 1 , seems to be quite high and suggests that, on average, Spanish regions may at least decrease their scale of operations (up to 26.6\%) to achieve the optimal scale. 
Table 1. Efficiency scores. Radial DEA Models. Average data 2005-2013

\begin{tabular}{|c|c|c|c|c|c|}
\hline Region & $\hat{\delta}_{\mathrm{CRS}}$ & $\hat{\delta}_{\mathrm{VRS}}$ & $\hat{\delta}_{\mathrm{NIRS}}$ & $\hat{\delta}_{\mathrm{SE}}$ & RTS \\
\hline Andalusia & 0.763 & 0.807 & 0.763 & 0.946 & IRS \\
\hline Aragon & 0.379 & 0.647 & 0.647 & 0.586 & DRS \\
\hline Asturias & 0.472 & 0.590 & 0.590 & 0.800 & DRS \\
\hline Balearic Islands & 1 & 1 & 1 & 1 & CRS \\
\hline Canary Islands & 1 & 1 & 1 & 1 & CRS \\
\hline Cantabria & 0.476 & 0.519 & 0.519 & 0.918 & DRS \\
\hline Castile-Leon & 0.483 & 0.941 & 0.941 & 0.513 & DRS \\
\hline Castile-La Mancha & 0.238 & 0.353 & 0.353 & 0.673 & DRS \\
\hline Catalonia & 0.614 & 0.824 & 0.824 & 0.746 & DRS \\
\hline Valencian Com. & 0.360 & 0.362 & 0.362 & 0.994 & DRS \\
\hline Extremadura & 0.458 & 1 & 0.458 & 0.458 & IRS \\
\hline Galicia & 0.483 & 0.882 & 0.882 & 0.547 & DRS \\
\hline Madrid & 0.615 & 1 & 0.615 & 0.615 & IRS \\
\hline Murcia & 1 & 1 & 1 & 1 & CRS \\
\hline Navarre & 0.308 & 0.321 & 0.308 & 0.957 & IRS \\
\hline Basque Country & 0.539 & 0.577 & 0.539 & 0.933 & IRS \\
\hline La Rioja & 0.154 & 0.326 & 0.154 & 0.472 & IRS \\
\hline Mean & 0.550 & 0.715 & 0.644 & 0.774 & \\
\hline Std. Dev. & 0.251 & 0.260 & 0.261 & 0.202 & \\
\hline
\end{tabular}

As an alternative to compare with the radial VRS model, the $\hat{\delta}_{\mathrm{VRS}}$ in Table 1 and Table 2 shows SBM VRS efficiency scores, $\hat{\delta}_{\mathrm{SBM}-\mathrm{VRS}}$, for the average data of the 2005-2013 period. As expected, the $\hat{\delta}_{\mathrm{SBM}-\mathrm{VRS}} \leq \hat{\delta}_{\mathrm{VRS}}$. Under this assumption the average efficiency score is 0.656 ( 0.606 for the average period data in Table 2).

The SBM model can provide an explanation of how a region can become efficient via the optimal slacks for inputs and output. The input excesses, Slack.x1 and Slack.x2 in Table 2, mean that in comparing to the best regions, inefficient ones should take this information as an indication of the output they should obtain to become relatively efficient. In this sense, the output shortfall, Slack.yl, provides the benchmark values.

Considering the average data for the period 20052013, the same efficient five regions under the VRS radial model, in Table 1, also remain efficient under the non-radial model in Table 2, i.e., they obtain a unitary $\hat{\delta}_{\mathrm{SBM}-\mathrm{VRS}}$ and null slacks in all inputs and in the output: Balearic Islands, Canary Islands, Extremadura, Madrid and Murcia. Several regions, such as Castile, La Mancha, Valencian Community, Aragon, Navarre and the Basque Country, should focus on increasing the output, perhaps by reallocating their accommodation capacity in different areas. In this sense, efficiency 
Table 2. Efficiency scores. SBM VRS DEA Model. Average data 2005-2013

\begin{tabular}{|c|c|c|c|c|}
\hline Region & $\hat{\delta}_{\text {SMB-VRS }}$ & $\begin{array}{c}\text { Slack.x1 } \\
\text { (NUMAR) }\end{array}$ & $\begin{array}{c}\text { Slack.x2 } \\
\text { (ACCOM) }\end{array}$ & $\begin{array}{c}\text { Slack.y1 } \\
\text { (BEDNIG) }\end{array}$ \\
\hline Andalusia & 0.789 & 2 & 0 & 0.7 \\
\hline Aragon & 0.356 & 5 & 6 & 6 \\
\hline Asturias & 0.434 & 3 & 4 & 1 \\
\hline Balearic Islands & 1 & 0 & 0 & 0 \\
\hline Canary Islands & 1 & 0 & 0 & 0 \\
\hline Cantabria & 0.435 & 2 & 1 & 3 \\
\hline Castile-Leon & 0.445 & 7 & 8 & 1 \\
\hline Castile-La Mancha & 0.220 & 4 & 4 & 11 \\
\hline Catalonia & 0.603 & 2 & 3 & 3 \\
\hline Valencian Com. & 0.360 & 0.2 & 0 & 8.8 \\
\hline Extremadura & 1 & 0 & 0 & 0 \\
\hline Galicia & 0.449 & 6 & 7 & 2 \\
\hline Madrid & 1 & 0 & 0 & 0 \\
\hline Murcia & 1 & 0 & 0 & 0 \\
\hline Navarre & 0.309 & 1.3 & 0 & 6.3 \\
\hline Basque Country & 0.577 & 0 & 0 & 5.9 \\
\hline La Rioja & 0.326 & 0 & 0 & 2.1 \\
\hline Mean & 0.606 & 1.914 & 1.941 & 2.984 \\
\hline Std. Dev. & 0.283 & 2.256 & 2.733 & 3.310 \\
\hline
\end{tabular}

determinants analysis can provide critical information from a strategic perspective.

Figure 1 shows the yearly average efficiency according to the SBM and VRS models. It can be observed that both models present approximately the same progression, with efficiency sinking during 2011 and 2012 and a resilient improvement in 2013, which is congruent with the traditional dynamism characterizing the tourism sector.

We also briefly analyze the productivity growth results from bootstrapped Malmquist Index decomposition. Table 3 contains the results for the average bootstrapped estimates of the changes in productivity, efficiency and technology for each period, including all the average data for the sample period 2005-2013: the Malmquist Index, MI, broken down into technological change (TC), the innovation or frontier shift component, and efficiency change (EC), the diffusion component. Moreover, the efficiency change is divided into pure efficient change, PEC, and scale efficient change, SEC.

The results indicate that, on average, productivity is approximately 1 for all periods in the sample; taking the entire period 2005-2013 into account, TC appears 


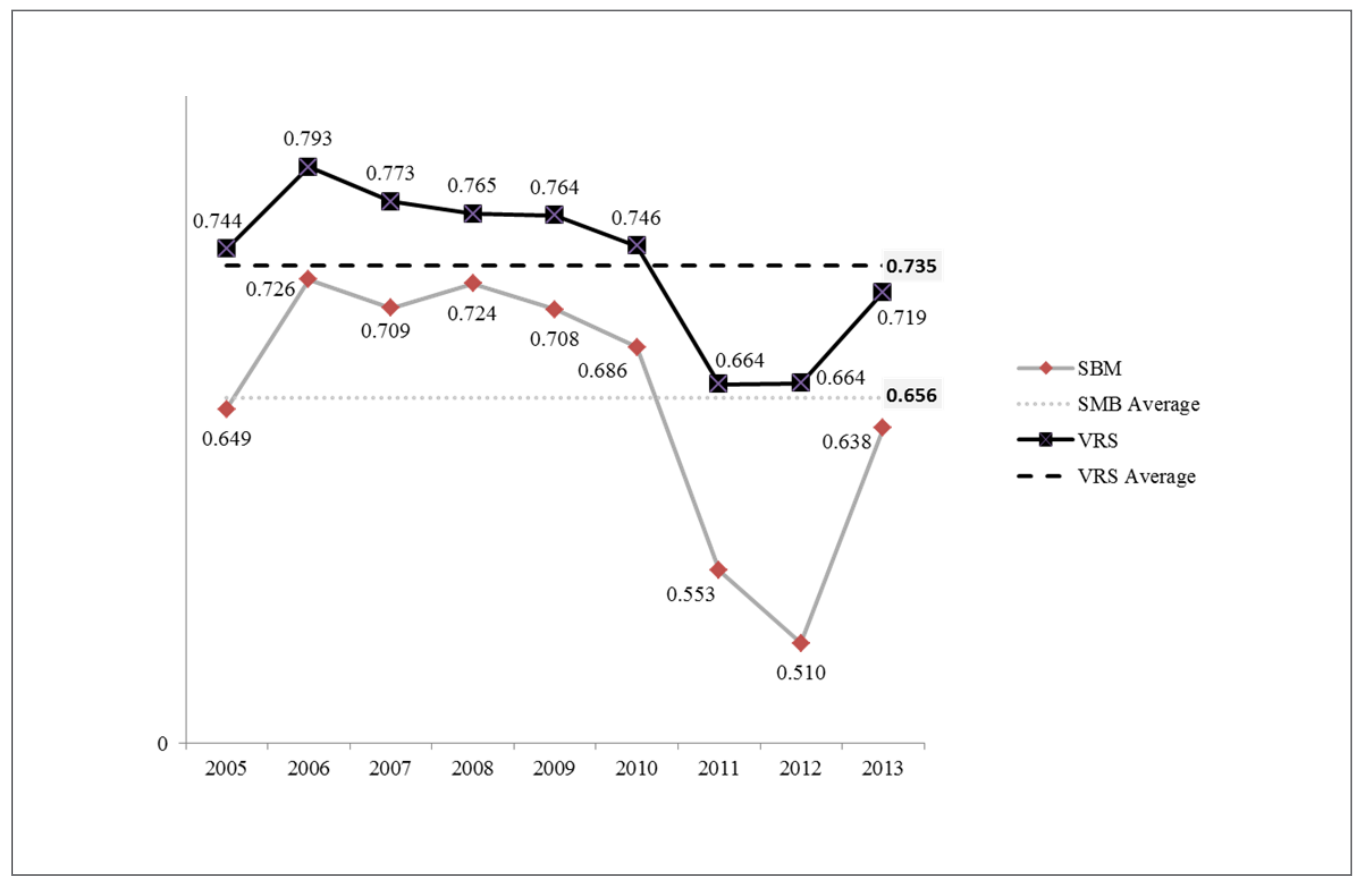

Figure 1. SBM and VRS efficiency. 2005-2013

to have a stronger contribution, which is illustrated by a $10 \%$ technical growth, whereas EC is slightly decreased by $10 \%$, a result that is in line with the DEA results (the degree of significance is based on $95 \%$ bootstrapped confidence intervals).

Table 3 also shows that seven of the eight periods experienced a significant decrease in productivity $(\mathrm{MI}<1)$. The years 2009-2010 alone reveal that MI>1. The average change in technical efficiency, EC, for 2005-2013 average data was $<1$ (0.908), which means that a decrease in technical efficiency for the majority of regions was produced, including in the areas of planning, expertise, management and organization. The breakdown of EC into PTE and SEC shows losses in PTE with a geometric mean of 0.905 and a geometric mean of 1.004 for SEC. Furthermore, the decrease in PEC reveals weaknesses in factors associated with management initiatives, such as marketing or quality. The SEC depends on size and, on average, improves during the period of study, which denotes that despite the inputs, some regions obtain economies of scale. Meanwhile, the average in technological change, TC, was 1.10 . Hence, innovation in procedures, techniques and methodologies did not deteriorate during the period studied.

The decrease in technical efficiency and more specifically, in PTE, is the most relevant factor in the example under analysis. Following Barros (2005, p. 181), this crucial member is a consequence of several factors; among them, in the Spanish case, structural rigidities associated with the labor market can be highlighted because they are potentiating the lack of a link between job tenure and performance. As an example, we can mention the Balearic Islands region.

\subsection{Efficiency Determinants and Stability Analysis}

Relative to the second-stage regression we have applied Simar and Wilson's (2007) algorithm-II (their Monte Carlo experiments confirm that it shows better functioning). In the two-stage Simar and Wilson (2007) procedure, the first stage estimated scores under the VRS assumption that are regressed in a truncated normal regression model on the group of environ- 
Table 3. Bootstrapped productivity, efficiency and technical changes. Geometric means

\begin{tabular}{|c|c|c|c|c|c|}
\hline Period & Malmquist Index & Efficiency Change & Technical Change & $\begin{array}{c}\text { Pure Efficiency } \\
\text { Change }\end{array}$ & $\begin{array}{c}\text { Scale Efficiency } \\
\text { Change }\end{array}$ \\
\hline $2005-2006$ & 0.997 & 1.154 & 0.864 & 1.073 & 1.076 \\
\hline 2006-2007 & 0.999 & 0.927 & 1.077 & 0.958 & 0.968 \\
\hline $2007-2008$ & 0.978 & 1.034 & 0.946 & 0.994 & 1.040 \\
\hline 2008-2009 & 0.986 & 1.010 & 0.976 & 1.003 & 1.007 \\
\hline $2009-2010$ & 1.032 & 0.908 & 1.137 & 0.992 & 0.915 \\
\hline $2010-2011$ & 0.987 & 0.839 & 1.176 & 0.784 & 1.071 \\
\hline $2011-2012$ & 0.991 & 0.859 & 1.154 & 0.963 & 0.892 \\
\hline $2012-2013$ & 1.021 & 1.242 & 0.822 & 1.179 & 1.053 \\
\hline $2005-2013$ & 0.999 & 0.908 & 1.100 & 0.905 & 1.004 \\
\hline
\end{tabular}

mental factors. Then, we constructed bootstrap 95\% confidence intervals for each estimated parameter. The model to solve at this stage can be expressed as follows $\left(\hat{\hat{\delta}}_{\mathrm{ij}}\right.$ represents the VRS DEA bootstrapped efficiency scores):

$\hat{\hat{\delta}}_{\mathrm{it}}=\alpha_{1} \operatorname{COAST}_{\mathrm{it}}+\alpha_{2} \mathrm{BICUL}_{\mathrm{it}}+\alpha_{3} \operatorname{MUSEUM}_{\mathrm{it}}+$

$+\alpha_{4} \mathrm{MICE}_{\mathrm{it}}+\alpha_{5} \mathrm{NATUR}_{\mathrm{it}}+\alpha_{6} \mathrm{GOLF}_{\mathrm{it}}+\alpha_{7} \mathrm{SKI}_{\mathrm{it}}+$

$+\alpha_{8} \mathrm{FOOD}_{\mathrm{it}}+\alpha_{9} \mathrm{SHOP}+\xi_{\mathrm{it}}$

Table 4 shows the results for the average data from the 2005-2013 period.

The first columns include the Shephard (1970) output VRS distance function estimates (Eff), the estimated bias (Bias), and the Shephard (1970) output VRS unbiased estimates (Rob-Eff). The next columns include the estimated coefficients, the lower and upper confidence interval limits, and the mean value of $\Omega$ within the period.

The model appropriately fits the data. The coefficients of COAST, MUSEUM, MICE, NATUR, SKI, FOOD and SHOP are all statistically significant in influencing the Spanish regions' performance, which can be considered tourist attractors. The negative sign of COAST is a signal that coastal regions are more efficient. Accordingly, the "see and sun" regions take advantage of this fact. Snow tourism and mountain sports have generally been growing in importance since the 1990s and are now a key attractor; the positive sign of SKI refers to regions with at least $1 \mathrm{~km}$ of skiable runs, which are more efficient than regions without skiable runs.

As efficiency is measured in terms of Shephard's (1970) output distance function, which is the reciprocal of the Farrell (1957) efficiency, the negative sign in MUSEUM, MICE, NATUR, FOOD and SHOP indicates a positive influence of these variables on performance. Finally, the remaining environmental variables, BICUL and GOLF, are not statistically significant at the $5 \%$ level (they are not significant at $10 \%$ either).

The Stability Analysis allows these results to be enriched by following the dependence of $\Omega$ over the years. The greater the value of $\Omega$, the stronger the significance of the attractor. Furthermore, a regular distribution of $\Omega$ indicates a stable influence. We have obtained regular patterns in all variables expect BICUL; despite its non-significance by the Simar and Wilson (2007) estimated coefficient, the mean value of $\Omega$ is close to unity, which may reflect the fact that efficiency is affected by small changes in this variable.

The remaining average values of $\Omega$ are consistent with the estimated coefficients obtained from the twostage procedure. As shown in Table 4, the attractor FOOD is the strongest significant variable, whereas 
Table 4. Efficiency Determinants and Stability Analysis. Average data 2005-2013

\begin{tabular}{|c|c|c|c|c|c|c|c|c|c|}
\hline \multirow{2}{*}{$\begin{array}{l}\text { Eff (1) } \\
1,240\end{array}$} & \multirow{2}{*}{$\begin{array}{c}\text { Bias } \\
-0.260\end{array}$} & \multirow{2}{*}{$\begin{array}{c}\text { Rob-Eff (2) } \\
1.499\end{array}$} & & \multicolumn{3}{|c|}{ Estimated Coefficients } & \multirow{2}{*}{$\begin{array}{c}\text { L.L. } \\
2.859\end{array}$} & \multirow{2}{*}{$\begin{array}{c}\text { U.L. } \\
18.411\end{array}$} & \multirow{2}{*}{$\begin{array}{c}\Omega(3) \\
-\end{array}$} \\
\hline & & & & Intercept & $\beta_{0}=$ & 9.35117 & & & \\
\hline 1,545 & -0.075 & 1.621 & $\mathrm{z} 1$ & COAST & $\beta_{1}=$ & -3.85485 & -9.048 & -0.757 & - \\
\hline 1,694 & -0.567 & 2.261 & $z 2$ & BICUL* & $\beta_{2}=$ & -0.00062 & 0.001 & 0.003 & 0.889 \\
\hline 1 & -0.562 & 1.562 & z3 & MUSEUM & $\beta_{3}=$ & -0.01640 & -0.060 & 0.028 & 6.523 \\
\hline 1 & -0.381 & 1.381 & $\mathrm{z4}$ & MICE & $\beta_{4}=$ & -0.44289 & -1.049 & -0.096 & 1.412 \\
\hline 1,929 & -0.805 & 2.733 & z5 & NATUR & $\beta_{5}=$ & -0.14798 & -0.374 & -0.013 & 3.411 \\
\hline 1,063 & -0.021 & 1.083 & z6 & GOLF* $^{*}$ & $\beta_{6}=$ & 0.02147 & -0.163 & 0.0194 & 0.645 \\
\hline 2,833 & -0.241 & 3.075 & $\mathrm{z7}$ & SKI & $\beta_{7}=$ & 0.02133 & -2.196 & 2.589 & - \\
\hline 1,214 & -0.148 & 1.362 & z8 & FOOD & $\beta_{8}=$ & -0.00143 & 0.000 & 0.004 & 8.422 \\
\hline 2,76 & -1.306 & 4.066 & z9 & SHOP & $\beta_{9}=$ & -0.00007 & -0.00024 & 0.00006 & 3.678 \\
\hline 1 & -0.822 & 1.822 & & & & & & & \\
\hline 1,133 & -0.027 & 1.161 & & & & & & & \\
\hline 1 & -0.528 & 1.528 & & & & & & & \\
\hline 1 & -0.886 & 1.886 & & & & & & & \\
\hline 3,111 & -1.740 & 4.851 & & & & & & & \\
\hline 1,732 & -0.440 & 2.172 & & & & & & & \\
\hline 3,068 & -1.441 & 4.509 & & & & & & & \\
\hline
\end{tabular}

Note:

(1) VRS efficiency estimates

(2) VRS unbiased efficiency estimates

* Statistically non-significant (for a significance level of 5\%)

(3) Mean value of $\Omega$ within the period 2005-2013

MICE is the weakest. Non-significant attractors are related to $\Omega$ less than unity, as can be clearly derived from the variable GOLF.

Spain's gastronomy enjoys an international reputation, and in recent years, there has been growth in the number of tourists whose main motivation for traveling to Spain is to sample its gastronomy. The significance obtained for the variable FOOD coincides with this social phenomenon, which has driven the development of tourist products and packages based on gastronomic routes. One peculiarity of Spanish attractors is Congress and Convention Tourism, which is under the variable MICE. The dynamism of this sub-sector favors de-seasonalization of tourist activity and raises the socio-economic impact of destinations because of the high daily expenditure profile of its visitors. Its significance was expected because according to data published by the ICCA (International Congress \& Convention Association), Spain ranked third in global rankings for this segment in 2013. However, only two CAs benefit from this attractor: Cataluña and Madrid.

\section{Discussion and conclusions}

Tourism is an economic sector with a clear lack of research methodologies and applied studies, and the use of parametric and semiparametric techniques is 
a forthcoming and promising area for future research because a tourism region can be considered a Decision-Making Unit that uses inputs to obtain outputs.

Our study rests on an appropriate choice of exogenous factors that best describes the situation of Spanish regions. Moreover, it is complemented by the choice of the DEA methodology and Malmquist productivity index with the aim of examining the efficiency and productivity change in Spanish regions for the 2005-2013 period.

With singular interest, this paper offers a new focus for analyzing determinants in tourism regions. Importantly, the link between the stability analysis and the use of Simar and Wilson's (2007) semiparametric twostage double bootstrap procedure is used to ascertain the extent to which the performance of Spanish tourism regions is determined by a group of contextual variables. Moreover, depending on data availability, the performance measure might include other inputs and/or outputs, e.g., sustainability, management, and strategic planning variables.

The efficiency and productivity analysis of Spanish regions during the 2005-2013 period is a good example of the sector's sensitivity. The unbiased efficiency average measure amounts to 0.44 (average Farrell type Rob-Eff in Table 4), suggesting that Spanish regions performed approximately $56 \%$ under their efficiency possibilities in these years. The productivity results follow the same trend.

At this stage in the literature development, there is a good basis of information of how to identify relevant attributes and, in particular, how to turn the focus of research toward assessing the relative importance of these attributes. Although the TTCI is the best known instrument used to rank nations according to their T\&T competitiveness, it is important to note that it is not a performance index.

It is true that Tourism Attraction may increase the sources of revenue and subsequently improve destination performance, but we need to know whether the determinants are statistically significant and to rank them. To this end, we have addressed a promising path. The significance of the factors under consideration, or lack thereof, can provide tourism policymakers with accurate information to use for future strategic decisions. Expert opinion is certainly a worthy mechanism, but mathematical programing techniques better allow us to draw the objective initial setting. Along these lines, the results in Table 4, and more concretely, the estimated coefficients in (7), have the correct sign and are statistically significant at $5 \%$ for COAST, MUSEUM, MICE, NATUR, SKI, FOOD and SHOP in influencing Spanish regions' performance when these coefficients are considered as tourist attractors.

The Stability Analysis strengthens knowledge concerning the significance of the exogenous variables. Non-significant attractors are related to values of $\Omega$ less than unity, whereas significant ones have a stronger impact as $\Omega$ grows. The latter fact allows the attractors to be classified as strong and weak.

Pressure is strong because Europe needs future growth from non-neighboring markets; rates should be therefore greater than world regions outside Europe; this is especially important for the BRIC (Brazil, Russia, India and China) economies. In this regard, the Russian market is about the same size as the US market, which is the key BRIC market for Europe. The Chinese market, if any, is about a quarter the size of the Russian market and is the second largest BRIC market for Europe. Brazil and then India rank third and fourth, respectively. Of course, BRIC countries are only a part of the market development strategy. Additional pressure comes from the following European Commission declaration and the shortage of financial funds, especially in Spain: "if Europe is to remain the world's number one tourist destination, tourism should not be taken for granted. Political efforts should be enhanced and supported with appropriate investment in priority areas to ensure future competitive growth and sustainable tourism development".

That said, an additional question remains regarding the sustainability of the touristic model. Spain is currently receiving more tourists than in previous years, and these tourists are spending more than before. At the same time, our mature model has moderated growth rates, so we are moving into an environment of increasingly strong competition where efficiency is the key subject. Following UNWTO recommendations, it is essential to foster responsible tourism in all aspects - economic, social and environmental - promoting sustainable growth as a consequence. Therefore, a future research line would be to perform a detailed analysis of the necessary link between performance and sustainability. A part of the Spanish success may 
come through some new phenomena that is far from sustainability, with a special mention of pubcrawling, or the act of one or more people drinking in multiple pubs or bars in a single night. The inclusion of some variables acting as undesirable outputs could be a way to examine this imperative link.

Future research for the 2013-2015 period may confirm these results and include other potential performance determinants. Since 2010, the European Union (EU) has clearly been involved and is worried about the tourist industry, aiming to stimulate competitiveness and performance in the sector. That said, a new paradigm must be open to create a new link between tourism and the public and private sectors. New types of consumer behavior are inevitably linked to a generalized increase in levels of income, as well as to the demographic evolution of Spain's main original markets. Tourism must therefore respond, which entails a radical rethinking of the traditional ways of defining, structuring and distributing tourist products. Inefficient Spanish regions must respond to individuals who are seeking integrated experiences that surpass their expectations. This "cluster services approach" is now considered essential to ensuring tourists' full satisfaction. There is therefore a need for competitive interdependence on the part of all actors at destinations taking into account the management model used by each destination. The expectation is that regions representing a "cluster attraction" will have a better future projection and will gradually gain in competitiveness.

This study presents several limitations. The performance of each region depends to some extent on the type of tourist considered: resident or non-residents. Furthermore, the exogenous variable selection is strategically crucial, and institutional involvement is required for deeper scrutiny.

In any case, the DEA technique offers new insights related to the topic of performance to be considered, i.e., the natural way to enhance competitiveness and performance.

\section{References}

Assaf, A., \& Agbola, F. W. (2011). Modelling the performance of Australian hotels: a DEA double bootstrap approach. Tourism Economics, 17(1), 73-89.

Assaf, A., Barros, C. P., \& Josiassen, A. (2012). Hotel efficiency: A bootstrapped metafrontier approach.
International Journal of Hospitality Management, 31(2), 621-629.

Assaf, A., Barros, C. P., \& Machado, L. P. (2011). The future outlook for Portuguese travel agents. Tourism Economics, 17(2), 405-423.

Assaf, A., \& Cvelbar, L. K. (2010). The performance of the Slovenian hotel industry: Evaluation Postprivatisation. International Journal of Tourism Research, 12(5), 462-471.

Assaf, A., Deery, M., \& Jago, L. (2011). Evaluating the performance and scale characteristics of the Australian restaurant industry. Journal of Hospitality \& Tourism Research, 35(4), 419-436.

Assaf, A., \& Josiassen, A. (2012). Identifying and ranking the determinants of tourism performance: A global investigation. Journal of Travel Research, 51(4), 388-399.

Assaf, A., \& Josiassen, A. (2016). Frontier analysis: A state-of-the-art review and meta-analysis. Journal of Travel Research, 55(5), 612-627.

Assaf, A., Josiassen, A., \& Cvelbar, L. K. (2012). Does triple bottom line reporting improve hotel performance? International Journal of Hospitality Management, 31(2), 596-600.

Banker, R. D., Charnes, A., \& Cooper, W. W. (1984). Some models for estimating technical and scale inefficiencies in data envelopment analysis. Management Science, 30(9), 1078-1092.

Barros, C. P. (2005). Evaluating the efficiency of a small hotel chain with a Malmquist productivity index. International Journal of Tourism Research, 7(3), 173-184.

Barros, C. P. (2008). Airports in Argentina: Technical efficiency in the context of an economic crisis. Journal of Air Transport Management, 14(6), 315-319.

Barros, C. P., Botti, L., Peypoch, N., Robinot, E., Solonandrasana, B., \& Assaf, A. (2011). Performance of French destinations: Tourism attraction perspectives. Tourism Management, 32(1), 141-146.

Barros, C. P., Botti, L., Peypoch, N., \& Solonandrasana, B. (2011a). Managerial efficiency and hospitality industry: the Portuguese case. Applied Economics, 43(22), 2895-2905.

Barros, C. P., \& Dieke, P. U. C. (2008a). Measuring the economic efficiency of airports: A Simar-Wilson methodology analysis. Transportation Research 
Part E-Logistics and Transportation Review, 44(6), 1039-1051.

Barros, C. P., \& Dieke, P. U. C. (2008b). Technical efficiency of African hotels. International Journal of Hospitality Management, 27(3), 438-447.

Barros, C. P., Managi, S., \& Yoshida, Y. (2010). Productivity growth and biased technological change in Japanese airports. Transport Policy, 17(4), 259-265.

Benito-López, B., Solana-Ibáñez, J., \& López-Pina, P. (2014). Determinants of Spanish regions' tourism performance: a two-stage, double-bootstrap data envelopment analysis. Tourism Economics, 20(5), 987-1012.

Botti, L., Peypoch, N., \& Solonandrasana, B. (2008). Time and tourism attraction. Tourism Management, 29(3), 594-596.

Crouch, G. I. (2007). Modelling destination competitiveness: a survey and analysis of the impact of competitiveness attributes. Gold Coast, Qld: Cooperative Research Centre for Sustainable Tourism.

Crouch, G. I. (2011). Destination competitiveness: An analysis of determinant attributes. Journal of Travel Research, 50(1), 27-45.

Crouch, G. I., \& Ritchie, J. R. B. (1994, June). Destination Competitiveness: Exploring Foundations for a Long-Term Research Program. Paper presented at the Administrative Sciences Association of Canada Annual Conference, Halifax, NS.

Crouch, G. I., \& Ritchie, J. R. B. (1995, July). Destination Competitiveness and the Role of the Tourism Enterprise. Paper presented at the Fourth Annual World Business Congress, Istanbul, Turkey.

Crouch, G. I., \& Ritchie, J. R. B. (1999). Tourism, competitiveness, and societal prosperity. Journal of Business Research, 44(3), 137-152.

Crouch, G. I., \& Ritchie, J. R. B. (2005). Application of the analytic hierarchy process to tourism choice and decision making. A review and illustration applied to destination competitiveness. Tourism Analysis, 10(1), 17-25.

Charnes, A., Cooper, W. W., \& Rhodes, E. (1978). Measuring the efficiency of decision making units. European Journal of Operational Research, 2(6), 429-444.

Dwyer, L., \& Kim, C. (2003). Destination competitiveness: Determinants and indicators. Current Issues in Tourism, 6(5), 369-414.
Dwyer, L., Mellor, R., Livaic, Z., Edwards, D., \& Kim, C. (2004). Attributes of destination competitiveness: a factor analysis. Tourism Analysis, 9(1-2), 91-101.

Enright, M. J., \& Newton, J. (2004). Tourism destination competitiveness: A quantitative approach. Tourism Management, 25(6), 777-788.

Färe, R., \& Grosskopf, S. (1985). A nonparametric approach to scale effciency. Scandinavian Journal of Economics, 87(4), 594-604.

Färe, R., Grosskopf, S., Lindgren, B., \& Roos, P. (1994). Productivity developments in Swedish hospitals: A Malmquist Output Index approach. In A. Charnes, W. W. Cooper, A. Y. Levin, \& L. M. Seiford (Eds.), Data envelopment analysis: Theory, methodology, and applications (pp. 253-272). Norwell, MA: Kluwer Academic Publishers.

Färe, R., Grosskopf, S., \& Lovell, C. A. K. (1985). The measurement of efficiency of production. Boston, MA: Kluwer-Nijhoff Publishing.

Färe, R., Grosskopf, S., Norris, M., \& Zhang, Z. (1994). Productivity growth, technical progress, and efficiency change in industrialized countries. The American Economic Review, 84(1), 66-83.

Farrell, M. J. (1957). The measurement of productive efficiency. Journal of the Royal Statistical Society. Series A (General), 120(3), 253-290.

Fuentes, R. (2011). Efficiency of travel agencies: A case study of Alicante, Spain. Tourism Management, 32(1), 75-87.

Gitto, S., \& Mancuso, P. (2010). Airport efficiency: A DEA two stage analysis of the Italian commercial airports (MPRA Working Paper No. 34366). University Library of Munich, Germany.

Gooroochurn, N., \& Sugiyarto, G. (2005). Competitiveness indicators in the travel and tourism industry. Tourism Economics, 11(1), 25-43.

Hathroubi, S., Peypoch, N., \& Robinot, E. (2014). Technical efficiency and environmental management: The Tunisian case. Journal of Hospitality and Tourism Management, 21, 27-33.

Heath, E. (2003). Towards a model to enhance destination competitiveness: A Southern African perspective. Journal of Hospitality and Tourism Management, 10(2), 124-141.

Malmquist, S. (1953). Index numbers and indifference surfaces. Trabajos de Estadística, 4, 209-242. 
Marco-Lajara, B., Úbeda-García, M., Sabater-Sempere, V., \& García-Lillo, F. (2014). Territory impact on the performance of Spanish vacation hotels. Tourism Economics, 20(4), 779-796.

Mazanec, J. A., Wöber, K., \& Zins, A. H. (2007). Tourism destination competitiveness: From definition to explanation? Journal of Travel Research, 46(1), 86-95.

Merkert, R., \& Assaf, A. (2015). Using DEA models to jointly estimate service quality perception and profitability - Evidence from international airports. Transportation Research Part A: Policy and Practice, 75, 42-50.

Perelman, S., \& Serebrisky, T. (2012). Measuring the technical efficiency of airports in Latin America. Utilities Policy, 22, 1-7.

Ribes, J. F., Rodriguez, A. R., \& Jiménez, M. S. (2011). Determinants of the competitive advantage of residential tourism destinations in Spain. Tourism Economics, 17(2), 373-403.

Ritchie, J. R. B., \& Crouch, G. I. (1993, October). Competitiveness in international tourism: A framework for understanding and analysis. Paper presented at the Proceedings of the 43rd Congress of the Association Internationale d'Experts Scientifique du Tourisme, San Carlos de Bariloche, Argentina.

Ritchie, J. R. B., \& Crouch, G. I. (2000a, June). Are destination stars born or made: Must a competitive destination have star genes? Paper presented at the Proceedings of the 31st Annual Travel and Tourism Research Association Conference, Burbank, CA.

Ritchie, J. R. B., \& Crouch, G. I. (2000b). The competitive destination: A sustainability tourism perspective. Tourism Management, 21(1), 1-7.

Ritchie, J. R. B., \& Crouch, G. I. (2003). The competitive destination: A sustainable tourism perspective. Wallingford, UK: CABI.

Shephard, R. W. (1970). Theory of cost and production functions. Princeton, NJ: Princeton University Press.

Simar, L., \& Wilson, P. W. (1998). Sensitivity analysis of efficiency scores: How to bootstrap in nonparametric frontier models. Management Science, 44(1), 49-61.

Simar, L., \& Wilson, P. W. (1999). Estimating and bootstrapping Malmquist indices. European Journal of Operational Research, 115(3), 459-471.
Simar, L., \& Wilson, P. W. (2007). Estimation and inference in two-stage, semi-parametric models of production processes. Journal of Econometrics, 136(1), 31-64.

Simar, L., \& Wilson, P. W. (2011). Two-stage DEA: caveat emptor. Journal of Productivity Analysis, 36(2), 205-218.

Simar, L., \& Wilson, P. W. (2015). Statistical approaches for non-parametric frontier models: A guided tour. International Statistical Review, 83(1), 77110.

Tone, K. (2001). A slacks-based measure of efficiency in data envelopment analysis. European Journal of Operational Research, 130(3), 498-509.

Trefethen, L. N., \& Bau, D., III. (1997). Numerical linear algebra. Philadelphia, PA: Siam.

Tsai, H., Song, H. Y., \& Wong, K. K. F. (2009). Tourism and hotel competitiveness research. Journal of Travel \& Tourism Marketing, 26(5-6), 522-546.

Tsekeris, T. (2011). Greek airports: Efficiency measurement and analysis of determinants. Journal of Air Transport Management, 17(2), 140-142.

Tsui, W. H. K., Gilbey, A., \& Balli, H. O. (2014). Estimating airport efficiency of New Zealand airports. Journal of Air Transport Management, 35, 78-86.

Wheelock, D. C., \& Wilson, P. W. (2008). Non-parametric, unconditional quantile estimation for efficiency analysis with an application to Federal Reserve check processing operations. Journal of Econometrics, 145(1-2), 209-225. 
